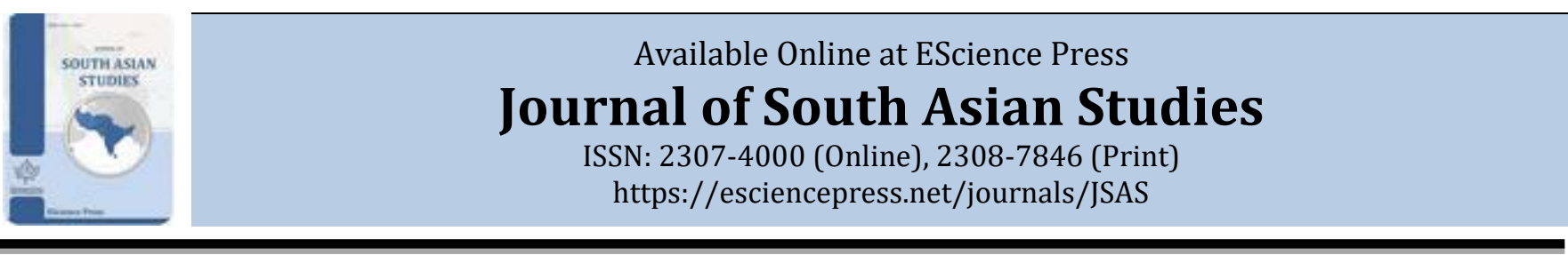

\title{
Elite Political Culture as Problematic for Liberal Democracy in Pakistan: A Critical Study
}

\author{
aMohammad Ashfaq*, aYasmin Roofi \\ a Department of Political Science, The Islamia University Bahawalpur, Bahawalpur, Punjab, Pakistan.
}

*Corresponding Author Email ID: mohammad_ashfaq@hotmail.com

\section{A B S T R A C T}

\begin{abstract}
The elite political culture of Pakistan is comparatively feudalistic in nature as the base of power in the state. Political culture may be defined as how many people participate in the political procedure. It is a system of beliefs upon which a large majority of people agree. The history of the political culture of Pakistan has witnessed the domination of multiple elite groups. These major elites had influences on the political system. Gaetano Mosca, the founder of the Italian school of elitism enumerated the personal traits of these ruling elites, operating centrally as direct power holders of the body politics, The purpose of this research is to critically study the elite political culture and problematics created by this group for liberal democracy. This research will present the concept of elite political culture and how it emerged in the politics of Pakistan. It will also conclude that how elite political culture distorted or eclipsed specifically the smooth functioning of the liberal democratic political system of the state and society in general. For the completion of the proposed study, both primary, as well as secondary sources, have been used. While undertaking any research a peculiar methodology is applied to obtain the objectives of the study. Historical, narrative, descriptive, analytical and conceptual research methodology is applied. This is a descriptive analysis of elitism and presents this concept through different authors who treated this subject in different manners.
\end{abstract}

Keywords: Elite political culture, Political System of Pakistan, Liberal Democracy, Problematics, Landlords.

\section{INTRODUCTION}

In the world of the 21 ist century, there is a deep-down disconnect in the theory and practice of democracy and it is replete with daunting complexities. The firm belief in the core values of democracy is startling, yet faith in empirical application in democratic dispensation remains elusive. Democratic engagement is followed through a faulty electoral process of settled, constant, and consistent preferences. These preferences are endogenous variables well embedded in the social system of third-world countries. Democratic values are facing erosion everywhere in the world. The answer to the problems of democracy is not less democracy but more democracy. Each model of democracy is connected with a practical set of principles of explanation, essential characteristics, and prevalent conditions. This paper is an effort to focus on the elite political culture of Pakistan and the role of feudal lords to make it impractical and serve their own vested interests by distorting the already weak democratic values and making the state institutions less responsive to address the socioeconomic and political issues of the people. The problematics of political polarization, elites and masses disconnect, rising economic inequalities will also be discussed.

\section{ELITISM OR ELITE POLITICAL CULTURE}

Elite political culture is the oldest theory of the world. It was developed at that time when the social concept of advancement was changed. Political culture may well define how people take part and how much they participate in political development. Political culture is a system of belief on which a great majority of the population agrees on it. Political culture also describes the nature of government and people's roles in government. Political culture "tries to explain that why 
people behave the way they do in terms not so much of their explicit desires, but rather in terms of what they believe about what government should be like and how it should be run"."Every nation and country of the world has its own political culture which comprises a set of beliefs, moral values, and customs. Political culture discusses the "attitude towards the political system and its various parts, and attitudes towards the self in the system." The political culture of a country or nation is the specific scattering patterns of alignment towards political concerns between the member of the country or nation (Girvetz, 1967: 40). Political culture is a powerful political concept of political science.

Gabriel Almond (1956) Almond and Verba (1963) said "it is to be an interaction between the persons affiliated with and groups linked to the internal political system of a country". It is defined as the traditional behavior of a nation's masses towards politics that affects their political legitimacy. Generally, it describes the behavior of a nation towards its national interest and politics. This political philosophy contains political beliefs and perceptions of a nation. It is a unique political culture of a people, state, or nation. Actual political cultures are one of the basic necessities that required achieving democratic rules (Haq, 2010).

If the political culture of Pakistan has to observe, it is very difficult to define it. Pakistan is a multi-cultural country with multi-linguistic multi-ethnic demography which is further divided into rural and urban areas. In the rural areas, the caste legacy played important role in the political system. In the perspective of Pakistan after independence, they introduced a Parliamentary democracy and the political elites played a significant and dominant role in shaping the political system (Kuper, 1987: 61) This political culture has greatly impacted the state, society and marginalized the masses. Which resultantly further distorted the social fabric of Pakistan.

\section{ELITES THEIR ROLE AND BEHAVIOUR IN THE POLITICAL SYSTEM OF PAKISTAN}

The word elite was a French word that was derived from the Latin word "eligere". It was refer to a small group of people that have powerful status, authority, and superior in the society (Akhtar, 2014). The word Elite had been used to define the commodities and particularly excelled in the 17th century. After this, it was used for a special higher group of people who were belonged to military and noble's classes. This term was applied as a social group in the 18th century in Oxford English Dictionary (Parry, 1977: 15). The elite theory was derived from the two sociologists Vilfredo Pareto and Gaetano Mosca. According to Pareto, the people are different physically as well as mentally in society and some people are blessed with more than others, who are called elites (Bottomore, 1964, pp. 7,49). He defined the elite as "a class of the people who have the highest indices in their branch of activity, and to that class given the name of the elite" (Coser, 1977, p. 397).

C. Wright Mills describes elites as "those economic, political and military circles, which as an intricate set of overlapping small but dominant groups share decisions having at least national consequence. In so far as national events are decided, the power elite is those who decided them (Martin Gilens, 2014). In simple words, the Elite is a superior and higher intellectual group of people who played a leading role in society. The elite class studies in well-known educational institutions of the world (Hashmat, 2018). Their education helps them to maintain their powers. Though Elite class is present and has their influence and significant role almost in all the societies of the world.

In Pakistan, the word elite refers to "a specific group that is part of government and administration has a strong character in the history of Pakistan. It imposed the greatest strain on the political system when it developed along ethnic lines. They are mostly belonging to landlords' families that existed during the British period. The major landowning elite group led to the ethnicization of political forces of the NWFP and Baluchistan on one side, Sind and Punjab on the other (Hussain, 1979). "However, over the years this began to change with the state civil and military bureaucracy getting integrated into the elite and also using state resources to create other elite groups" (Siddiqa, 2012). The powerful elites in Pakistan easily receive control and dominate the society but the evolution of elites is related to the ability of power. The middle class and lower middle class also get an elite position in politics like Altaf Hussain, Tahir-ul-Qadri is the best example of this elite group (Hashmat, 2018). Asif Hussain divided the elites' class into three groups. These three groups are 'traditional, colonial, and emergent. The traditional group belonged to the period of Muslim rule, colonial to the period of British rule (1857-1947) and emergent elites were those that become politically active in the 
post-1947 period" (Rizvi, 2015: 55).

Each elite group was continually engaged in mobilizing its resources to transform the state to safeguard its vested interests. With such transformations in mind, each regime emphasized some ideology to legitimize their systems" (Rizvi, 2015). Political elites are very powerful people which hold most of the power in politics than the common people. Political elites had leading positions and use power in the political system (Hussain, 1979: 34-35). These elites became the central part of the cabinet of the Pakistan government.

Saeed Shafqat mentioned five kinds of elites "military elites, bureaucratic elites, industrial elites, political elites, and religious elites. Some elite groups such as military, bureaucracy, and industrial are dominant over other elite groups (Shafqat, 1997: 24). According to Saeed Shafqat, "Political elites, who led the nationalist movement which had a high mobilization capacity they inherited weak or almost non-existent political institutions". "In the absence of political institutions, they fell on bureaucracy. On the other hand, the Muslims-merchant class who provided the initial finance for the Pakistan movement and also migrated to Pakistan emerged as an important coalitional component" (Shafqat, 1997: 26-27). He further stated "In 1958 when the military acted to resolve the crisis and then a new ruling coalition was evolved. This change of regime meant defining new rules which were EBDO changed the role of the political elite and with that new farmers and new industrial commercial-industrial class appeared. Bureaucratic and military elites were dominant in this period and during the 1970 election, the nature and role of Islam were encouraged as an ideological component.

It was under such an environment that Z.A. Bhutto (1971-77) had to formulate a ruling coalition and rejuvenate the structural components of Pakistan's political system" (Shafqat, 1997: 29-30,36). "Pakistan People Party (PPP) "which was an umbrella organization, representing interests of feudal, middle class, intelligentsia, students and labor." It also had sympathizers in the military and bureaucracy. However political elite who dominated the decision-making had social origins in the feudal and urban middle class" (Shafqat, 1997: 36).

(LaPorte, 1975: 1) dividing the Pakistani people into four groups. These are the modern ruling elite, educated middle class, students, and provincial rural and urban dwellers. The modern ruling elite is known as military officers, Civil service officers, and top businessmen. Dr. Farzana Rizvi criticized the describing groups of Robert La Port (Rizvi, 2015: 57). She further states "There are three major but overlapping elite groups in Pakistan: Political, Economic and Social." These elite groups in Pakistan are military officers, civil service officers, Industrial, religious, professional and landowning families" (Rizvi, 2015: 59).

The military elites are the dominant group in the political culture of Pakistan. In Pakistan common people have no knowledge of politics, they believe in strong military power due to weak political institutions and lack of capable political leadership after the demise of Quaid-e-Azam. After independence in 1947 conflicts started with India such as the Kashmir issue and water dispute, which dictates to establish a powerful Army. Furthermore, Political parties like Muslim League and political institutions rapidly declined. In this situation, military elites gained a dominant position in Pakistan.

Samuel Edward Finer describes three reasons which make the military superior. It has three enormous political advantages over civil institutions; control over arms, and extremely emotionalized symbolic status and marked superiority in the organization" (Finer., 1962: 5) Inflexible military training and massive defense budget improved the professional character and status of the Army. Civilian power weakened day by day which ultimately led to military power and General Ayub dismisses Iskander Mirza on 7th October 1958. It was the time of the first Martial Law in Pakistan. The second Martial law came with General Yahya Khan on 25th March 1969. He was resigned after the debacle of East Pakistan now Bangladesh on 16th December 1971 (Zaheer., 1994: 78).

On 5th July 1977, General Zia-ul-Haq enforced the third Martial Law and discharged the popular civilian government of Pakistan People's Party. General Zia-ulHaq announced, "He will hold free, fair and transparent polls in October 1977 and will shift authority to the democratic government" but he Kept suspended elections for Eight years. He died in an airplane crash on 17th August 1988 and democracy was restored again in Pakistan. Unfortunately 12th October 1999 again the democratic government of Nawaz Sharief was suddenly ended by General Pervaiz Musharraf. Pakistan had come under Martial law for the fourth time in Pakistan's history. The army always gave the same reason every 
time that they took over law and order has not been maintained properly and the economy is on verge of collapsing (Hashmat, 2018, p. 20). The military have always an effective role to play in the domestic and foreign affairs of the country even during the civilian rule" (Waqar, July 2012).

Bureaucracy means people of high rank in the government, who pay them a vast amount as a salary. According to Khan "Bureaucracy means the grouping of bureaucrats, who include all government servants, accept those who are popularly elected" (Khan, 2006: 423). Max Weber explains that "well trained bureaucratic professionals prevail against the less expert ministers who run the administrative divisions, the cabinet which directs the state legislature which makes decisions and policies." Bureaucracy has the actual power and commands of the administration of the state (Hashmat, 2018: 22). They contribute to all the key decisions related to the state such as administrative, security measures, foreign policy, and financial. Actually, they run all the business of government. They are mostly belonging to the well-known landowning and elite families of the country.

The political system of Pakistan is replete with rampant corruption, nepotism, favoritism, and red-tapism. The power and influence of bureaucratic elites are increasing day by day. In Pakistan, these bureaucrats are the real depiction of these predictions and guess. In Pakistan, bureaucrats have complete powers and authority which used for their own desires. "They obtain the task of consultant, specialists, advisers, policymakers, and policy executers. In Pakistan bureaucracy is very much powerful, because Pakistan inherited an iron steel bureaucracy from our colonial masters who also led them to have an attitude of the ruler" (Kalia, 2013).

The industrial revolution started during the era of General Ayub Khan had supported the twenty-two families for business and industry. Almost these families owned 80 percent of the economy, industry, and business of the country which resulted in the formulation of industrial elites. In Pakistan, the role of Industrial elites is not satisfactory. They abuse poor labor and only give them sustenance wages. They don't even pay taxes and they hoard goods. They pressurize the government for their personal benefits by forming economic cartels. These industrial elites and crony capitalism, use their money in different political parties which allow them to influence the government policies
(Hashmat, 2018: 24).

Pakistan is an Islamic republican state and has many types of religious elites. They morally and spiritually guide Muslim society. They lead Muslims at the time of several religious rituals and festivals. Religious elites played a very important role in Pakistani Islamic society. The religious groups were present in Pakistan at the time of Independence and have an influence on society but have no effective presence in the National and Provisional Assembly. Religious elites appeared as a powerful group during the Zia-ul-Haq period of Islamization and Afghan Jihad. The number of Madrassas increased ran by different religious groups. Madrassas, where religious education was given but extremism, was also taught at some Madrasses, so it has become controversial and there are some concerns of the international community (Butt, 2012: 393). Some religious groups like the Taliban and Al-Qaeda were involved in terrorist activities against the state of Pakistan. They killed the masses, officials, businessmen, and political leaders by suicide attacks, bomb blasts, and target killing. They are also involved in kidnapping activities for ransom. These activities strained the reputation of Pakistan at the International level. Some other religious groups work by forming a party and taking part in elections and only a few votes are given to them but they exert great pressure on the government. These religious elites like Maulana Fazal Rahman, Tahiru ul-Qadri, and leaders of Jammat-e-Islami are working as pressure groups. They all have the street powers and use them to pressurize the elected governments to fulfill their personal benefits by Dharnas, Inqalab Long March, and the recent Azadi March launched by Fazalur Reman. These religious elites prefer Martial Laws instead of democratic governments because they cannot gain power through votes (Hashmat, 2018: 23).

Judiciary is one of the most important parts of the state. People look to the judiciary for the assurance and guarantee of their fundamental rights and for justice. It protects the rights of citizens by stopping wrong actions of any individual or department. Supreme Court checks every executive decision and then approves them or checks them but the judiciary has always played a different role in Pakistan. Judicial elites firstly appeared in 1955 in Pakistan when chief justice M. Munir took a controversial decision. He supports the action of Governor-General Ghulam Mohammad when he dissolves the first Constitutional Assembly of Pakistan. 
Chief Justice M. Munir stated that the Assembly was not a supreme body in the Maulvi Tamizuddin Khan case. This Chief Justice again supports President Iskander Mirza's action, dissolving the National Assembly and the 1956 constitution of Pakistan.

The Supreme Court solidly permitted General Zia-ul-Haq to become a dictator and created the Doctrine of Necessity. Supreme Court rejected the appeal of Nusrat Bhutto that was against the arrest of Zulfiqar Ali Bhutto under Martial Law. The bench of nine judges of the Supreme Court supported the Martial Law and called Martial Law a necessity owing to bad law and order situations and rigging in elections. Supreme Court refused to restore the government of Junejo in 1988, dismissed by General Zia-ul-Haq. President Ghulam Ishaq Khan dismissed the Benazir Bhutto government in 1990 and Nawaz Sharif Government in 1993 and dissolved the National Assembly of Pakistan.Supreme Court declare the dissolving of Nawaz Sharif Government in 1993 unlawful action but when President Farooq Leghari dismissed Benazir Bhutto government in 1997 court supported this action. Supreme Court also provided shelter to the fourth Martial Law of General Pervaiz Musharraf in 1999. The courts always provided an umbrella for Martial Law or the military elite's takeover of democratic governments of Pakistan. The courts had played an important role in abolishing the liberal democratic system in the state (Hashmat, 2018: 23-24).

The people who have vast agricultural land are called landlords. They are owners of thousands of acres of land and present since the British Raj. People who supported the British East India Company received a vast amount of land as gifts. It created a group of the elite landlord that remained in power even after the independence in 1947 and still a big challenge for the political system of Pakistan. Their titles are Chaudhary, Sardar, Rajas, Malik, Nawab, Ranas, Shahas, and Nawabzadas.

This powerful group, feudal lords affected every socioeconomic and political sector of the country because of their power, privilege, and position. Most of them study from abroad and after coming back they become part of executive posts of bureaucracy, Judiciary, military, and police. This nexus is difficult to break and affects the political system. They are present in every Parliament and every type of government of Pakistan (Hashmat, 2018: 20). All these political elite take part in politics and play a very important role in distorting the political culture.

\section{LIBERAL DEMOCRACY}

The word democracy is created from the demos that mean people, so well it turns into the rule of people. It is a kind of government in which the actual and supreme power belongs to the people and is applied by the elected representatives that are elected through a balloting system. Democracy is a system of governance and interest representation demands respect for conflict and opposition. It identifies the principle of majority rule and assurances protection of minorities. Democracy also builds faith in democratic contestation to gain public office and gives validity to political parties as primary instruments for the attainment and transfer of power from one set of individuals to another. In democracy people basically express their will and work with independence. According to Francis Fukuyama, "liberal democracy is more than majority voting in elections, it is a complex set of institutions that restrain and regularize the exercise of power through law and a system of checks and balance" (Fukuyama, 2013). The state must practice the principle of equal citizenship to all irrespective of religion, caste ethnicity and regional background. It must also ensure the quality of opportunity to all for advancement in social, political, and economic domains and guarantee the security of life and property of its citizens.

The word Liberal derives from the Latin word "liber" meaning free. It was first used in 1815 and liberal started used in politics in the 19th century. Liberalism is believed in freedom of speech, independence, and equal rights. John Locke who is also regarded as the father of 'classical liberalism' emphasized individualism and popular sovereignty i.e. today's liberal democracy. Liberalism supports social progress by changing laws and reforms than revolution. A loose definition of democracy can be taken as 'government of the people, by the people and for the people. But how much of that is really practical has been the topic of debate for centuries. One of the major critics of the 'rule of the majority has been Hobbes who preferred autocratic rule or the 'master's rod' for men to follow the laws of nature (Schofeld, 2008: 179). Today in the world, the democratic index identifies a total of 75 democracies (flawed or full) out of a total of 167 countries excluding only microstates.

Pakistan is an Islamic democratic country but it has not experienced a stable consolidation of democracy in seventy years of its history. The democracy facing many 
problems since 1947 due to the reason of political ineffectiveness, the role of political elites, military performance, political situation, deficiencies, (Adnan \& Fatima, 2018: 157) well-developed party system, lack of roots of constitutionalism, and fair and free election. The political elites like politicians, industrialists, and feudal lords are failed to provide the liberal democracy according to the constitutions. They cheated the trust of the people of Pakistan in the name of democracy because the character of political leaders is not clear. (Adnan \& Fatima, 2018: 162) They have blamed the charges of corruption. The uncontrolled corruption in Pakistan is creating a threat and negative effects on the democracy by elite political culture.

The appreciated aim of attaining a liberal democracy in Pakistan failed to take appropriate roots. There are many reasons for failure but they are mainly due to the political elite. Thomas Carothers' 'elite capture' is by extension the real-world realization of a locking form of government that permits only 'male property owners to vote. Carothers points out that liberal democracy will eventually fall into the hands of the wealthy that will then maneuver the policies of the government to suit their personal interests.

Elite political culture or aristocracy is not something alien to real-existing democracies although sometimes it can be seen hiding behind the mask of democracy. A member of the aristocracy or an aristocrat enjoys privileges that lower classes of societies do not include but are not limited to intellectual supremacy which makes them 'fit to govern'. The modern election process makes way for elective aristocracy as money plays an important part in election campaigns in the New World Order. "The availability of financial resources to contest well-financed election campaigns on an ever-larger scale has become a key to success in competition for elected political power.

Even though many governments limit the finances involved in elections, a concept of 'soft money' has surfaced which can be used on activities that indirectly influence the election campaigns. Big donors 'purchase influence' on election campaigns and the candidates. The candidates when elected want to keep the donors happy and make policies to facilitate or promote their interests. This is the elective form of aristocracy given birth to by the 'liberal democracy' and lurks behind the curtain of representative governments or parliamentary forms of government. Democracy in Pakistan is on the regressive path. Therefore, it can fairly be said that the democracy of today revolves around money which is a luxury owned by the elites. This has reduced the liberal democracy into an aristocracy.

\section{CONCLUSION}

The elite political culture defines that a small group of people containing the members of different organizations, institutions, and powerful families hold great power. The political elites play a negative and positive role but in developing countries like Pakistan, they played a negative role. They dominate over the whole society and political system. All political elite tried to control the government institutions through secret alliances, nexuses, cartels and effectively exert influences over the policies and decisions of the government, semi-government and private organization. There is also a great disconnect between people and elites. They have a lot of roles, power, and wealth to gain a dominant position in society. They eliminate the strengthening pillars of political institutions. They do not believe in delivering and good governance but their own agenda to follow. They use state machinery and resources to achieve and promote their personal benefits. Since they had no clear vision to deliver and good governance in the country. They badly exploit society in one pretext or another. They spread corruption and weaken the institutions for achieving their personal benefits. Unfortunately, all political parties have not played their role to check this rot, but they do provide the platform to the different elites groups. There is a great need for the state to take speedy right steps in order to ensure their work with their abilities and remove corruption and de-politicization of civil service (Adnan \& Fatima, 2018: 162). At the same time, ethnic and sectarian issues are major hurdles to achieving a long-term sustained democracy. If we have to strengthen the political institutions, we have to ensure political participation of common people, implement the rule of law, educate the society, and restrict the government servants for only performing their official duties. Similarly, the democratic procedure must be continued that would not only minimize or eliminate the role of political elites but also shift existing political culture into liberal democratic culture for the progress and prosperity of the country. 


\section{REFERENCES}

Adnan, M., \& Fatima, B. (2018, January-June). Political, Economic and Social Governance in Pakistan: Its Practices and Issues. Journal of the Research Society of Pakistan, 55(1), 157-171.

Akhtar, N. (2014). Akhtar N. (2014). The Dynastic Elites and its Recruitment in Political Process of Pakistan. Berkeley Journal of Social Sciences, 4 (3).19-24.

Bottomore, T. B. (1964). Elites and Society. Middlesex: Penguin Books Ltd.

Butt, T. M. (2012). ButSocial and Political Role of Madrassa: Perspectives of Religious Leaders in Pakistan. South Asian Studies, 27(2), 387-407.

Coser, L. A. (1977). Masters of Sociological Thought: Ideas In Historical and Social Context. New York: Harcourt Brace Jovanovich, Inc.

Finer., S. E. (1962). The Role of the Military in Politics. . West view Press United States.

Fukuyama, F. (2013). What is Governance. Governance, 26(3). 347-368.

Girvetz., H. k. (1967). Democracy and Elitism: Two Essays with Selected readings. New York: Charles Scribner's Sons.

Haq, N. U. (2010). Governance and Democracy in Pakistan: Weaknesses, Strengths and Prospects (Vol. X). Islamabad: IPRI.

Hashmat, U. K. (2018). Role of Elites in Pakistan. International Journal of Applied Economic Studies, 6(1), 19-24.

Hussain, A. (1979). Elites and political development in Pakistan. The Developing Economies, 14(3), 224238.
Kalia, S. (2013). Bureaucratic Policy Making in Pakistan. Tthe Dialogue, 8(2), 156-170.

Khan, S. (2006). Public Administration with Special Reference to Pakistan. Lahore: Famous Book.

Kuper, J. (1987). Political Science and Political Theory,. London: Routledge \& Kegan Paul.

LaPorte, R. (1975). Power and Privilege: Influence and Decision-Making in Pakistan. California: University of California Press.

Martin Gilens, B. I. (2014). Testing Theories of American Politics: Elites, Interest Groups, and Average Citizens. Perspectives on Politics, 12(3), 564-4881.

Parry, G. (1977). Political Elite. London: George Allens \& Unwin Publishers Ltd. Fifth Impression.

Rizvi, F. (2015). Circulation of Elite in West and in Pakistan: Historical Perspective. Journal of the Punjab University of Historical Society, 28(1), 4164.

Schofeld, N. J. (2008). Political Economy of Democracy and Tyranny. Oldenbourg.

Shafqat, S. (1997). Civil Military Relations in Pakistan: From Zulfiqar Ali Bhutto to Benazir Bhutto. Colorado: West view Press.

Siddiqa, A. (2012, June 30). What is Pakistan Elite?" The Express Tribune, July 1st. Retrieved 2021, from tribune.com.pk.

Waqar, S. (July,2012). Military Bureaucratic Elite's Target, Weak Political Institution in Pakistan. Presented in the 22nd Political Science World Congress in Madrid, Spain. Madrid Spain.

Zaheer., H. (1994). The Separation of East Pakistan-The Rise and Realization of Bengali Muslim Nationalism. Karachi: Oxford University Press.

Publisher's note: EScience Press remains neutral with regard to jurisdictional claims in published maps and institutional affiliations.

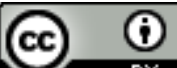

EY Open Access This article is licensed under a Creative Commons Attribution 4.0 International License, which permits use, sharing, adaptation, distribution and reproduction in any medium or format, as long as you give appropriate credit to the original author(s) and the source, provide a link to the Creative Commons license and indicate if changes were made. The images or other third-party material in this article are included in the article's Creative Commons license, unless indicated otherwise in a credit line to the material. If material is not included in the article's Creative Commons license and your intended use is not permitted by statutory regulation or exceeds the permitted use, you will need to obtain permission directly from the copyright holder. To view a copy of this license, visit http://creativecommons.org/licenses/by/4.0/.

(C) The Author(s) 2021. 